\title{
Impact of Mechanical Transplanting on Rice Productivity and Profitability- Review
}

\author{
Rajesh Saha ${ }^{1}$, Partha Sarathi Patra ${ }^{2 *}$ and Arju Sahid Ahmed ${ }^{1}$ \\ ${ }^{1}$ Dept. of Agronomy, Uttar Banga Krishi Viswavidyalaya, Pundibari, Cooch Behar, W.B. (736165), India \\ ${ }^{2}$ Regional Research Station, Terai Zone, Uttar Banga Krishi Viswavidyalaya, P.S- Pundibari, Cooch Behar, W.B. (736 165), India
}

\section{Corresponding Author}

Partha Sarathi Patra

e-mail: parthaagro@gmail.com

\author{
Article History \\ Article ID: IJEP0418d \\ Received on $13^{\text {th }}$ April, 2021 \\ Received in revised form on $25^{\text {th }}$ October, 2021 \\ Accepted in final form on $21^{\text {st }}$ November, 2021
}

\begin{abstract}
Conventional rice transplanting methods are laboured exhaustive and involves drudgery. On an average only transplanting operation takes one fourth of the total labour requirement of rice production under traditional system. Shifting of agricultural labourer towards urban areas for better remuneration creates labour shortage during peak time of transplanting. Lower plant density compared to desirable level under traditional transplanting method habitually farmers force to apply higher amounts of agro-input to compensate as result cost of cultivation has increased considerably and eventually get lesser grain yield. Under such circumstances, a cheap and labour redeemable way of rice transplanting without compromising grain yield is the need of the time. The mechanical rice transplanting is an alternative and encouraging choice for ensuring timely transplanting and also contributes to higher grain yield. Mechanical transplanting of rice is profitable over traditional methods and easy to operate. In spite of having superiority over the conventional transplanting, acceptance in the field level is stumpy due to high preliminary investment and dearth of awareness in growing mat type nursery. Divulging technical skill, confirming timely accessibility and boosting custom hiring may be some of the practical solutions for increasing the adoption rate of mechanical transplanting among farmers. This review focused on the positive and negative impact of mechanical transplanting on productivity and profitability of rice production.
\end{abstract}

Keywords: Mechanical transplanting, productivity and economics, rice

\section{Introduction}

Among the cereals, rice (Oryza sativa L.) is one of the most vital crops because it is the principal food for the majority of Indian population. In order to meet the food demand of the rising population country has to produce about $137.29 \mathrm{mt}$ of rice by 2030-31 with an annual incremental rate of $2.15 \%$ (Pathak, 2020). Indian farmers grow rice either by manual transplanting or by direct seeding method (Kumar et al., 2016 and 2017). Manual transplanting is more common among farmers because it gives comparatively higher yield than direct seeding method, besides it is labour-exhaustive and involves more energy (Verma, 2010). On an average, traditional method of rice transplanting required 238 man hour per hectare (Dixit and Khan, 2011). Manjunatha et al. (2009), also testified pleasing result of mechanical transplanter, where 3 man-days was sufficient to transplant one hectare compared to 33 man days in case of traditional transplanting system. Labour requirements in rice production accounts for the maximum input cost (Clayton, 2010). Continued submerged rice cultivation over eras has led to weakening of soil physical properties through structural degradation of soil aggregates and capillary pores and clay dispersion thus limiting germination and rooting of succeeding crops (Tomar et al., 2006). Recently many research has emphasized the challenges with manual transplanting in puddled soil comprising huge yield differences (Lobell et al., 2009) compared to other establishment techniques, poor water and nutrient use efficiencies (Humphreys et al., 2010; Sudhir-Yadav et al., 2011b), emits considerable amounts of greenhouse gases (Wassmann et al., 2004), escalating shortage of man-power (Devkota et al., 2019a,b), and allied augmented pays (SudhirYadav et al., 2017; Bandumula et al., 2018). Together, these vagaries have amplified the workload of women (Akter et al., 2017), resulted into higher production cost and condensed profitability (Ditzler et al., 2018).

Furthermore, plant population is reasonably low in manual transplanting method, which forces the farmers to use additional nitrogenous fertilizer to boost tillering, which usually outcomes in multifarious biotic stresses and eventually lower yields. Gill and Walia (2013) opined that yield determinants like length of panicle and 100 grain weight were statistically at par among different establishment methods in rice, but number of grains panicle ${ }^{-1}$ was significantly higher with machine transplanted rice. 
At present Indian agriculture is tremendously suffering due to lack of manpower in general and skilled manpower in particulars. Immigration of agricultural labourer to the urban areas, non-farm employment openings having exciting remunerations and low eminence in the society are the major reasons for labour crisis during peak sowing time. As a result crops are not sown or planted timely. Delayed sowing or planting actually expose the crops against unfavourable climatic condition and prevalence of pest attack which leads to lower production. To ensure planting at right time and also to achieve ideal plant population mechanical transplanting had been found encouraging choices for attaining maximum yield (Tripathi et al., 2004; Manjunatha et al., 2009). Incremental grain yield with self-propelled walk behind type and self-propelled four wheels type transplanters over conventional method was noticed by Manesh et al. (2013). Baldev et al. (2013) noted 3 to $11 \%$ yield advantage by machine transplanting as compared to conventional puddled transplanted rice. Pasha et al. (2012) also found higher grain yield of rice with yangi eight row transplanter over conventional transplanting owing to more tillering ability, filled grains panicle ${ }^{-1}$ and more number of panicle hill.

Among all agro-techniques inducing grain yield of mechanically transplanted rice, age of seedling is the most significant aspect (Shen et al., 2006). Seedling age less than 25 days is considered ideal for achieving higher yield in mechanical method. Accurate running of the transplanters and lessening root damage, three weeks old seedling were found appropriate (Aswini et al., 2009). Significant yield reduction had been noticed whenever transplanted aged seedling through mechanical method (Islam et al., 2008; Liu et al., 2015; Liu et al., 2017). So in order to achieve good yield and impressive return proper land preparation and timely transplanting are the keys of success under mechanical method. In spite of having superiority over the conventional transplanting method, small land holding and feeble financial status of the Indian farmers are the major shortcomings for the adoption of this technology.

This review scrutinizes the affirmative and deleterious impression on yield and economic of mechanized rice production.

\section{Related Literatures}

\subsection{Effect of plant population}

Optimum plant population is one of the most significant factors for attaining maximum yield. In manual transplanting, 30-40 days old root eroded seedlings are used while root washed and soil attached seedlings are used in mechanical transplanting. The soil adhered with seedling works as connecting components, which assists to uphold homogeneity, seedlings establishments, minimize transplanting tremor and inhibits floating, which are the key criterion for mechanical transplanting. Transplanting at proper depth and distance actually helps in maintaining optimum population by mechanical method (Singh and Vatsa, 2006). In order to achieve optimum plant population for higher yield and to curtail labour necessity mechanical transplanting appears to be most suitable way (Farooq et al., 2001; Tripathi et al., 2004).

\subsection{Effect on growth attributes}

It is established fact that, transplanting at proper time, depth and distance by mechanical transplanter helped in quick establishment and thereby enhanced cell division and enlargement which results in higher plant height as compared to conventional method (Singh and Rao, 2010; Kang et al., 2019). Timely transplanting along with correct spacing through mechanical method promotes leaf emergence and expansion. Higher number of leaves and larger leaf area ultimately helped in synthesis of more photosynthesis and thereby more dry matter accumulation (Kang et al., 2019).

In order to achieve more dry matter with better apportioning towards panicle followed by stem and leaf, transplanting of 25 days old seedling was ideal (Vijayalaxmi et al., 2016). Gangwar et al. (2008) found higher shoot and root dry matter of rice under wet bed drum seeding method compared to manual and mechanical transplanting. Roots of wider spaced rice grow mechanically have encountered minimum competition over traditional method and thereby growth is activated by solar radiation and create enough space for canopy development (Rajesh and Thanunathan, 2003).

\subsection{Effect on yield attributes}

Among the yield attributes, number of effective tillers $\mathrm{m}^{-2}$, panicle length, number of filled grains panicle ${ }^{-1}$ and test weight are the dominant parameter contributing grain yield. Highest number of effective tillers $\mathrm{m}^{-2}$ was obtained in mechanically transplanted rice, due to transplantation of younger seedling (less than 25 days old) at proper distance and depth which minimized transplanting tremors and brings about early establishment and effectual exploitation of growth factors (Manjunatha et al., 2009). Mechanical transplanting improved number of panicles hill-1 and fertile grains panicle ${ }^{-1}$ (Sheeja et al., 2012).

Pasha et al. (2012) observed longest panicle $(23.61 \mathrm{~cm})$ and maximum number of grains per panicle (156) with machine transplanting in comparison with broad casting, drum seeding and conventional method of transplanting.

Sreenivasulu et al. (2014) reported that mechanical transplanting helped in improvement of yield attributes namely number of productive tiller, panicle length, number of grains panicle ${ }^{-1}$ and test weight of rice over manual method (Figure 1).

\subsection{Effect on grain yield}

Final yield of crops are the collective contribution of yield determinants. Higher the yield attributes higher will be the yield. Incremental yield was witnessed in mechanical transplanting over conventional method, might be due to transplanting of younger seedlings with appropriate spacing 


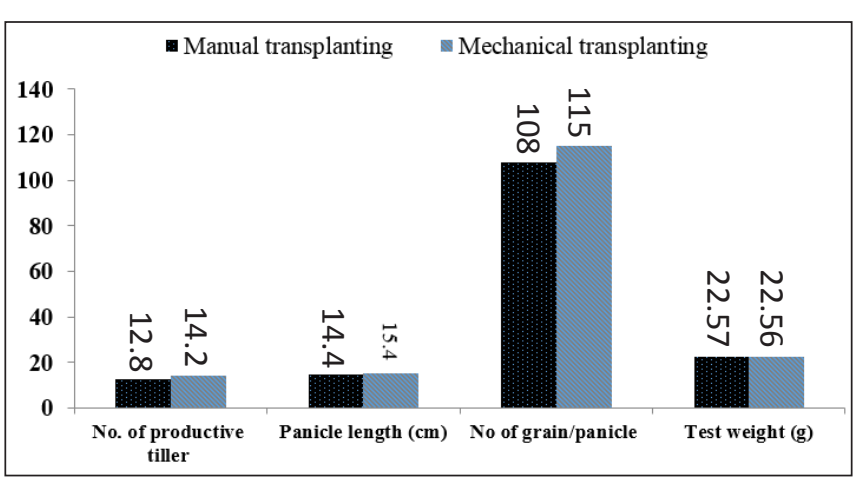

Figure 1: Comparative performances of yield attributes of rice under manual and mechanical method

and depth, which utilized the growth resources capably and facilitated enhanced translocation of photo assimilates from source to sink leading to higher number of productive tillers $\mathrm{m}^{-2}$ and thereby increased number of filled grains panicle $^{-1}$ and finally higher grain yield (Manjunatha et al., 2009; Kumar et al., 2012). 200-240 $\mathrm{kg}$ acre $^{-1}$ higher yield was obtained whenever transplanting was done mechanically over manual transplanting with the same levels of inputs (Farooq et al., 2001). Singh and Vatsa, 2006 was also found $30-35 \%$ yield advantage through mechanical method than hand transplanting. Mechanical transplanting augmented yield by $5.71 \%$ and $3.80 \%$ over manual and broadcast transplanting (Yao et al., 2000) might be due to early tillering, development of more panicles on earlier tillers, longer panicles, extended active leaf life and decreased rate of leaf area reduction.

Grain yield of 21 days old seedling transplanted mechanically and manually at a spacing of $30 \times 12 \mathrm{~cm}^{-2}$ was found statistically similar (Kang et al., 2019). Under intensive rice-wheat system, delayed harvesting of wheat and adverse weather conditions along with lack of transplanter often causing seedlings to age. Transplanting of aged seedling with machine significantly resulted into lower grain yield compared to artificial transplanting due to reduction of tiller emergence, photosynthetic efficiency and assimilate remobilization efficacy (Liu et al., 2015).

Singh et al., (2006) reported that among the different methods of rice transplanting, mechanical method was found superior and offered $23.04 \%, 36.92 \%$ and $62.80 \%$ higher grain yield over manual, dry direct seeding and wet direct seeding respectively (Table 1 ).

\subsection{Effect on economics}

Success or failure of any technology depends on its economic feasibility. Conventional method of rice transplanting needs more man power in the operations like land preparation for seedling rising, uprooting of seedlings, carrying of seedlings to main field and transplanting over mechanical method (Sreenivasulu et al., 2014). More man power involvement in seed bed preparation, uprooting, transportation and planting ultimately heightened the total cost of cultivation in manual method. Mechanization with SRI technology minimized the
Table 1: Yields and harvest index of rice (variety: Saket-4) as influenced by different establishment methods

\begin{tabular}{lcccc}
\hline $\begin{array}{l}\text { Planting } \\
\text { methods }\end{array}$ & $\begin{array}{c}\text { Grain } \\
\text { yield } \\
\left(\mathrm{t} \mathrm{ha}^{-1}\right)\end{array}$ & $\begin{array}{c}\text { Straw } \\
\text { yield } \\
\left(\mathrm{t} \mathrm{ha}^{-1}\right)\end{array}$ & $\begin{array}{c}\text { Biological } \\
\text { yield } \\
\left(\mathrm{t} \mathrm{ha}^{-1}\right)\end{array}$ & $\begin{array}{c}\text { Har- } \\
\text { vest } \\
\text { index }\end{array}$ \\
\hline Manual & 4.34 & 4.72 & 9.06 & 0.480 \\
Mechanical & 5.34 & 5.52 & 10.86 & 0.492 \\
$\begin{array}{l}\text { Dry direct } \\
\text { seeding }\end{array}$ & 3.90 & 4.86 & 8.72 & 0.446 \\
$\begin{array}{l}\text { Wet direct } \\
\text { seeding }\end{array}$ & 3.28 & 4.54 & 7.82 & 0.420 \\
$\mathrm{CD}(p=0.05)$ & 0.190 & 0.512 & 0.575 & 0.025 \\
\hline
\end{tabular}

seed and labour requirements to the extent of 50 and $60 \%$ respectively, thereby lessen the production cost by $27 \%$ and increase the earnings by $36 \%$ ha $^{-1}$ (Uprety et al., 2010). Mechanical transplanting become profitable to adopt as it gives yield aids due to higher population stand (Farooq et al., 2001). Saving in labour cost in one hand and higher yield in another side helped in getting higher gross return, net return and benefit: cost (Mohapatra et al., 2012; Sheeja et al., 2012). Mohanty and Barik (2010) also reported $34.46 \%$ incremental benefit cost ratio in mechanical method over manual transplanting method.

Sajitha and Jayakiran, 2010 reported lower gross return in machine planting while net returns and $\mathrm{B}$ : $\mathrm{C}$ ratio was higher compared to line transplanting as of the low cost incurred in transplanting and nursery preparation. Pasha et al. (2014) was conducted an experiment during 2011-12 to evaluate the superiority of the diverse crop establishment methods in puddled rice and found that drum seeding gave the highest net return.

\section{Conclusion}

Mechanized transplanting can be used magnificently as an economic, practicable and alternative opportunity for attaining higher productivity and curtail the cost of farming as the traditional rice transplanting needs more workforce.

\section{References}

Akter, S., Rutsaert, P., Luis, J., Htwe, N.M., San, S.S., Raharjo, B., Pustika, A., 2017. Women's empowerment and gender equity in agriculture: a different perspective from Southeast Asia. Food Policy 69(C), 270-279.

Aswini, G.K., Swain, S., Debaraj, B., 2009. Effect of seedling age on performance of rice transplanter. Agricultural mechanization in Asia, Africa and Latin America 40(3), 41-46.

Baldev, R.K., Dharam, B.Y., Ashok, Y., Narender, K.G., Gurjeet, G., Ram, K.M., Bhargirath, S.C., 2013. Mechanized transplanting of rice (Oryza sativa L.) in nonpuddled and no-till conditions in the rice-wheat cropping system 
in Haryana, India. American Journal of Plant Sciences 12(4), 2409-2413.

Bandumula, N., Mahajan, G., Kumar, R.M., 2018. Farm level and aggregate economic impact of direct seeded rice in Punjab. Journal of Experimental Biology and Agricultural Sciences 6(1), 253-257.

Clayton, S., 2010. 50 years of Rice Science for a better world - and it's just the start. Rice Today, IRRI. pp.12.

Devkota, K.P., Pasuquin, E., Elmido, A.M., Dikitanan, R., Singleton, G.R., Stuart, A.M., Duangporn, V., Vidiyangkura, L., Pustika, A.B., Listyowati, C., Keerthisena, R.S.K., Thi, N.K., Malabayabas, A.J., Hu, R., Pan, J., Beebout, S.J., 2019a. Economic and environmental indicators of sustainable rice cultivation: a comparison across intensive irrigated rice cropping systems in six Asian countries. Ecological Indicators 105(1), 199-214.

Devkota, M., Devkota, K.P., Acharya, S., McDonald, A.J., 2019b. Increasing profitability, yields and yield stability through sustainable crop establishment practices in the rice-wheat systems of Nepal. Agricultural System 173(C), 414-423.

Ditzler, L., Breland, T.A., Francis, C., Chakraborty, M., Singh, D.K., Srivastava, A., Eyhorn, F., Groot, J.C.J., Six, J., Decock, C., 2018. Identifying viable nutrient management interventions at the farm level: the case of smallholder organic Basmati rice production in Uttarakhand, India. Agricultural System 161(C), 61-71.

Dixit, J., Khan, J.N., 2011. Comparative field evaluation of selfpropelled paddy transplanter with hand transplanting in valley lands of Kashmir region. Agricultural Mechanization in Asia, Africa, and Latin America 42(2), 14-18.

Farooq, U., Sheikh, A.D., Muhammad, I., Bashir, A., Anwar, Z., 2001. Diffusion possibilities of mechanical rice transplanters. International Journal of Agricultural Biology 3(1), 17-18.

Gangwar, K.S., Gill, M.S., Tomar, O.K., Pandey, D.K., 2008. Effect of crop establishment methods on growth and productivity and soil fertility of rice (Oryza sativa L.) based cropping system. Indian Journal of Agronomy 53(2), 102-106.

Gill, J.S., Walia, S.S., 2013. Quality and grain yield of basmati rice as influenced by different establishment methods and nitrogen levels. An Asian Journal of Soil Science 8(2), 311-318.

Humphreys, E., Kukal, S.S., Christen, E.W., Hira, G.S., Singh, B., Yadav, S., Sharma, R.K., 2010. Halting the groundwater decline in North-West India -which crop technologies will be winners? Advances in Agronomy 109, 155-217.

Islam, M.S., Hossain, M.A., Chowdhury, M.A.H., Hannan, M.A., 2008. Effect of nitrogen transplanting date on yield and yield components of aromatic rice. Journal of Bangladesh Agricultural University 6(2), 291-296.

Kang, J.S., Kaur, J., Sandhu, S.S., 2019. Performance of mechanically transplanted Basmati rice (Oryza sativa L.) under different age of seedling and planting densities. Indian Journal of Agronomy 64(2), 200-203.

Kumar, A., Nayak, A.K., Mohanty, S., Das, B.S., 2016. Greenhouse gas emission from direct seeded paddy fields under different soil water potentials in Eastern India. Agriculture, Ecosystem and Environment 228, 111-123.

Kumar, A., Nayak, A.K., Pani, D.R., Das, B.S., 2017. Physiological and morphological responses of four different rice cultivars to soil water potential based deficit irrigation management strategies. Field Crops Research 205, 78-94.

Kumar, V.D., Babu, H.B., Reddy, M.K., 2012. Self-propelled walking behind type rice transplanter - A better alternative for manual transplanting. The Andhra Agricultural Journal 59 (4), 630-634.

Liu, Q., Wu, X., Ma, J., Chen, B., Xin, C., 2015. Effect of delaying transplanting on agronomic traits and grain yield of rice under mechanical transplanting pattern. PLoS One 10(4), e0123330.

Liu, Q., Zhou, X., Li, J., Xin, C., 2017. Effects of seedling age and cultivation density on agronomic characteristics and grain yield of mechanically transplanted rice. Scientific Reports 7, 14072.

Lobell, D.B., Cassman, K.G., Field, C.B., 2009. Crop yield gaps: their importance, magnitudes, and causes. Annual Review of Environment and Resources 34(1), 179-204.

Manesh, G.S., Dixit, A., Singh, A., Mahal, J.S., Mahajan, G., 2013. Feasibility of mechanical transplanter for paddy transplanting in Punjab. Agricultural mechanization In Asia, Africa, and Latin America 44(3), 14-17.

Manjunatha, M.V., Reddy, B.G.M., Shashidhar, S.D., Joshi, V.R., 2009. Studies on the performance of self-propelled rice transplanter and its effect on crop yield. Karnataka Journal of Agricultural Sciences 22(2), 385-387.

Mohanty, D.K., Barik, K.C., 2010. Comparitive performance of eight row self-propelled rice transplanter and manual transplanting ar farmer's field. Agriculture Engineering Today 34(4), 87-92.

Mohapatra, P.C., Din, M., Parida, B.C., Pate, S.P., Mishra, P., 2012. Effect of mechanical planting and weeding on yield, water use efficiency and cost of production under modified system of rice system of intensification. Indian Journal of Agricultural Sciences 82(3), 280-283.

Pasha, L., Bhadru, D., Krishna, L., Naik, R.B.M., 2012. Comparative performance of different rice planting methods under Nagarjuna sagar project left canal command area of nalgonda district. Crop Research 44(1-2), 1-4.

Pasha, M.D., Reddy, R.R., Badru, D., Krishna, L., 2014. Evaluation of different crop establishment techniques in puddled rice (Oryza sativa L.). The Journal Research ANGRAU 42(2), 13-16.

Pathak, H., 2020. Agricultural research and development: 
policy and program priorities in India. Agricultural Policy and program framework: Priority Areas for Research \& Development in South Asia 5, 93-115.

Rajesh, V., Thanunathan, K., 2003. Effect of seedling age, number and spacing on yield and nutrient uptake of traditional Kambanchamba rice. Madras Agricultural Journal 90(1-3), 47-49.

Rani, T.S., Jayakiran, K., 2010. Evaluation of different planting techniques for economic feasibility in rice. Electronic Journal of Environmental, Agricultural and Food Chemistry 9(1), 150-153.

Sheeja, K.R., Mathew, R., Jose, N., Leenakumary, S., 2012. Enhancing the productivity and profitability in rice cultivation by planting methods. Madras Agricultural Journal 99(10-12), 759-761.

Shen, J.H., 2006. Effects of sowing density, fertilizer amount in seedbed and seedling age on seedling quality and grain yield in paddy field for mechanical transplanting rice. Acta Agronomica Sinica 32(3), 402-409.

Singh, K.K., Lohan, S.K., Jat, A.S., Rani, T., 2006. New technology of planting rice for higher production. Research on Crops 7(2), 369-371.

Singh, R.S., Rao, K.V.R., 2010. Impact of self-propelled transplanter in rice. Electronic Journal of Environmental Agricultural and Food chemistry 9(1), 150-153.

Singh, S., Vatsa, D.K., 2006. Performance of evaluation of PAU manual transplanter in hills of himachal Pradesh. Agricultural Engineering Today 30(3), 43-46.

Sreenivasulu, S., Bala, P., Reddy, H., 2014. Effect of mechanized transplanting on yield, yield attributes and economics of rice (Oryza sativa). The Journal Research ANGRAU 42(2), 9-12.

Sudhir, Y., Humphreys, E., Kulkal, S.S., Gill, G., Rangarajan, R., 2011. Effect of water management on dry seeded and puddled transplanted rice: Part 2: water balance and water productivity. Field Crops Research 120(1), 123-132.
Sudhir, Y., Kumar, V., Singh, S., Kumar, R.M., Sharma, S., Tripathi, R., Nayak, A.K., Ladha, J.K., 2017. Growing rice in Eastern India: New paradigms of risk reduction and improving productivity. The Future Rice Strategy for India, 221-258.

Tomar, R.K., Singh, D., Gangwar, K.S., Garg, R.N., Gupta, V.K., Sahoo, R.N., Chakraborty, D., Kalra, N., 2006. Influence of tillage systems and moisture regims on soil physical environment, growth and productivity of rice-wheat system in upper Gangatic plains of Western Uttar Pradesh. Indian Journal of Crop Science 1 (1-2), 146-150.

Tripathi, S.K., Jena, H.K., Panda, P.K., 2004. Self-propelled rice transplanter for economizing labour. Indian Farming 54, 23-25.

Uprety, R., 2010. Meshing mechanization with SRI methods in Nepal. In: $3^{\text {rd }}$ International Rice Congress, 8-12 November, Vietnam.

Verma, A., 2010. Modelling for mechanization strategies of rice cultivation in Chhattisgarh, India. Ama, Agricultural Mechanization in Asia, Africa and Latin America 41(1), 20-26.

Vijayalaxmi, G., Sreenivas, G., Leela Rani, P., Ram Prakash, T., 2016. Influence of plant densities and age of seedlings on dry matter partitioning and grain yield potential of transplanted rice (Oryza sativa L.). International Journal of Current Research in Biosciences and Plant Biology 3(4), 51-55.

Wassmann, R., Neue, H.U., Ladha, J.K., Aulakh, M.S., 2004. Mitigating greenhouse gas emissions from riceewheat cropping system in Asia. Environment Development and Sustainability 6, 65-90.

Yao, Y.M., Shen, M.X., Sun, H., 2000. Effect of transplanting of rice seedling in pots on growth characteristics and yield single cropping late rice. Jiangsu Agricultural Science 34(1), 13-15. 